\title{
The Fiscal Deficit and Economic Growth in Pakistan: New Evidence
}

\author{
Nasir Iqbal*, Musleh ud Din ${ }^{* *}$ and Ejaz Ghani ${ }^{* * *}$
}

\begin{abstract}
This study revisits the relationship between the fiscal deficit and economic growth in Pakistan to determine whether there exists a threshold fiscal deficit that might serve as a benchmark for policymakers aiming to promote growth through fiscal expansion. We apply the smooth transition autoregressive model to time-series data for the period 1972-2014. The empirical analysis shows that the threshold level of fiscal deficit is 5.57 percent of GDP, above which the deficit has a negative impact on growth. Overall, the fiscal deficit has a negative impact on economic growth, mainly because it has tended to remain above the threshold level. However, there is room for fiscal policy to promote growth, provided the fiscal deficit is kept below the threshold level and public spending is channeled into productive investments that raise the country's long-term growth potential.
\end{abstract}

Keywords: Fiscal deficit, threshold level, economic growth, STAR, Pakistan.

JEL classification: $\mathrm{H} 12, \mathrm{O} 47, \mathrm{C} 24$.

\section{Introduction}

The role of the fiscal deficit in economic growth has been debated extensively in the literature. Studies based on the neoclassical school of thought argue that the fiscal deficit impedes economic growth by putting pressure on the interest rate on the back of increased government borrowing, which crowds out private investment. Other studies, following the Keynesian approach, argue that the fiscal deficit can stimulate domestic production, leading to economic optimism among private investors and

\footnotetext{
* Director Research, Benazir Income Support Program, Islamabad, Pakistan.

** Professor, Pakistan Institute of Development Economics, Islamabad, Pakistan.

*** Professor, Pakistan Institute of Development Economics, Islamabad, Pakistan.

The views expressed in this article are those of the authors and do not reflect the views of the Benazir Income Support Program or the Pakistan Institute of Development Economics. The authors remain responsible for any errors or omissions.
} 
resulting in more investment - what is known as the "crowding-in" effect (Bernheim, 1989). Proponents of rational expectations postulate that debtfinanced expansionary fiscal policy has no role in stimulating demand because agents expect future increases in taxation and adjust their spending accordingly (under the Ricardian equivalence hypothesis). An expansionary fiscal policy leads to a decrease in government saving, which triggers an offsetting increase in desired private saving. As a result, desired national saving does not change at all. Consequently, the real interest rate does not have to rise to maintain a balance between national saving and investment demand, leaving overall output unchanged (Saleh \& Harvie, 2005).

The empirical evidence on the impact of the fiscal deficit on growth is inconclusive. One strand of the literature indicates a positive association between the fiscal deficit and economic growth, while other studies find a negative relationship. These mixed findings suggest the possibility of a nonlinear relationship between the fiscal deficit and economic growth. This, in turn, implies there may be a threshold level of fiscal deficit that indicates the extent to which fiscal expansion can serve as a growth-promoting policy instrument.

Several recent empirical studies have explored the existence of this threshold effect in the relationship between the fiscal deficit and economic growth. Adam and Bevan (2005) find evidence of a threshold effect at a fiscal deficit of about 1.5 percent of GDP for developing countries, indicating that fiscal deficits higher than this would hamper economic growth. Other studies find a threshold effect at significantly higher levels of the fiscal deficit - about 5-7 percent of GDP for selected countries, depending on the structure and openness of the economy, the political system and institutional arrangements (see, for example, Onwioduokit, 2012, 2013; Aero \& Ogundipe, 2016). This study explores the relationship between the fiscal deficit and economic growth in the case of Pakistan. Its objective is to identify a threshold level of fiscal deficit that can serve as a benchmark for macroeconomic policy.

Pakistan's economy has two notable features. First, despite a historical average growth rate of over 5 percent, it has experienced numerous ups and down in economic performance, with high-growth periods followed invariably by sharp slowdowns (Iqbal, Khan \& Irfan, 2008). Second, these high-growth (low-growth) periods have been recently characterized by lower (higher) levels of fiscal deficit. During 2002-07, the average fiscal deficit was 3.5 percent, with an average GDP growth rate of over 5 percent. However, during 2008-15, the average fiscal deficit was 6.3 
percent, with an average GDP growth rate of 3.3 percent. The overall budget deficit declined substantially from 8.2 percent of GDP in FY2013 to 4.6 percent of GDP in FY2016, primarily due to better expenditure management during the recent recovery period. The country's growth experience seems to imply that the economy tends to perform well in periods of moderate fiscal deficit, while higher fiscal deficits have been associated with economic growth. This suggests that there may be a threshold level of fiscal deficit that policymakers can target to promote economic growth while maintaining macroeconomic stability.

A key feature of this study is that it uses the smooth transition autoregressive (STAR) model to investigate the possible presence of a threshold level of fiscal deficit. The model uses a continuous transition function to capture the nonlinear relationship between the variables of interest. This is unlike earlier studies, which use either a squared term to estimate the threshold level (see Ali \& Ahmad, 2010; Qasim, Kemal \& Siddique, in press) or the threshold model developed by Khan and Senhadji (2001) to calculate threshold inflation (see Aero \& Ogundipe, 2016; Onwioduokit, 2012, 2013; Onwioduokit \& Bassey, 2014).

The rest of the article is structured as follows: Section 2 provides an overview of fiscal indicators in Pakistan. Section 3 presents a brief review of the literature. Section 4 explains the data, modeling framework and estimation method used. Section 5 presents our empirical results. Section 6 provides some concluding remarks and policy implications.

\section{Fiscal Indicators: An Overview}

The objective of recent fiscal efforts in Pakistan has been to sustain macroeconomic stability, while ensuring an environment that is conducive to economic growth. This has entailed reducing the fiscal deficit without cutting development expenditures (State Bank of Pakistan, 2016). Table 1 shows that the overall budget deficit has declined substantially from 8.2 percent of GDP in FY2013 to 4.6 percent in FY2016, largely due to better expenditure management (Pakistan, Ministry of Finance, 2017). 
Table 1: Fiscal indicators, as percentage of GDP

\begin{tabular}{lccccccc}
\hline \multirow{2}{*}{ Year } & $\begin{array}{c}\text { Overall fiscal } \\
\text { deficit }\end{array}$ & Total & Current & $\begin{array}{c}\text { Develo } \\
\text { pment }\end{array}$ & Total & Tax & Nontax \\
\cline { 3 - 8 } & 4.0 & 17.1 & 12.6 & 4.5 & 13.1 & 9.8 & 3.3 \\
2006 & 4.1 & 19.5 & 14.9 & 4.6 & 14.0 & 9.6 & 4.4 \\
2007 & 7.3 & 21.4 & 17.4 & 4.0 & 14.1 & 9.9 & 4.2 \\
2008 & 5.2 & 19.2 & 15.5 & 3.5 & 14.0 & 9.1 & 4.9 \\
2009 & 6.2 & 20.2 & 16.0 & 4.4 & 14.0 & 9.9 & 4.1 \\
2010 & 6.5 & 18.9 & 15.9 & 2.8 & 12.3 & 9.3 & 3.0 \\
2011 & 8.8 & 21.6 & 17.3 & 3.9 & 12.8 & 10.2 & 2.6 \\
2013 & 8.2 & 21.5 & 16.4 & 5.1 & 13.3 & 9.8 & 3.5 \\
2014 & 5.5 & 20.0 & 15.9 & 4.9 & 14.5 & 10.2 & 4.3 \\
2015 & 5.3 & 19.6 & 16.1 & 4.1 & 14.3 & 11.0 & 3.3 \\
2016 & 4.6 & 19.9 & 16.1 & 4.5 & 15.3 & 12.6 & 2.7 \\
$2017 \mathrm{BE}$ & 3.8 & 19.8 & 15.0 & 4.7 & 16.0 & 12.9 & 3.1 \\
\hline
\end{tabular}

Source: Pakistan Economic Survey for 2016/17.

The State Bank of Pakistan (2016) attributes the reduction in the budget deficit to the following three factors:

- Over 20 percent growth in tax collections by the Federal Board of Revenue.

- A fall in debt servicing expenses, which has helped contain the growth in federal current expenditures.

- Higher surpluses recorded by the provincial governments.

This reduction in the budget deficit has also been accompanied by healthy growth in revenues and a slight contraction in total expenditure as a percentage of GDP (Figure 1). The overall tax-to-GDP ratio, which was 9.8 percent of GDP in FY2013, increased to 11.0 percent in FY2015 and 12.9 percent in FY2016 (Pakistan, Ministry of Finance, 2017). 


\section{Figure 1: Revenue-expenditure gap, as percentage of GDP}

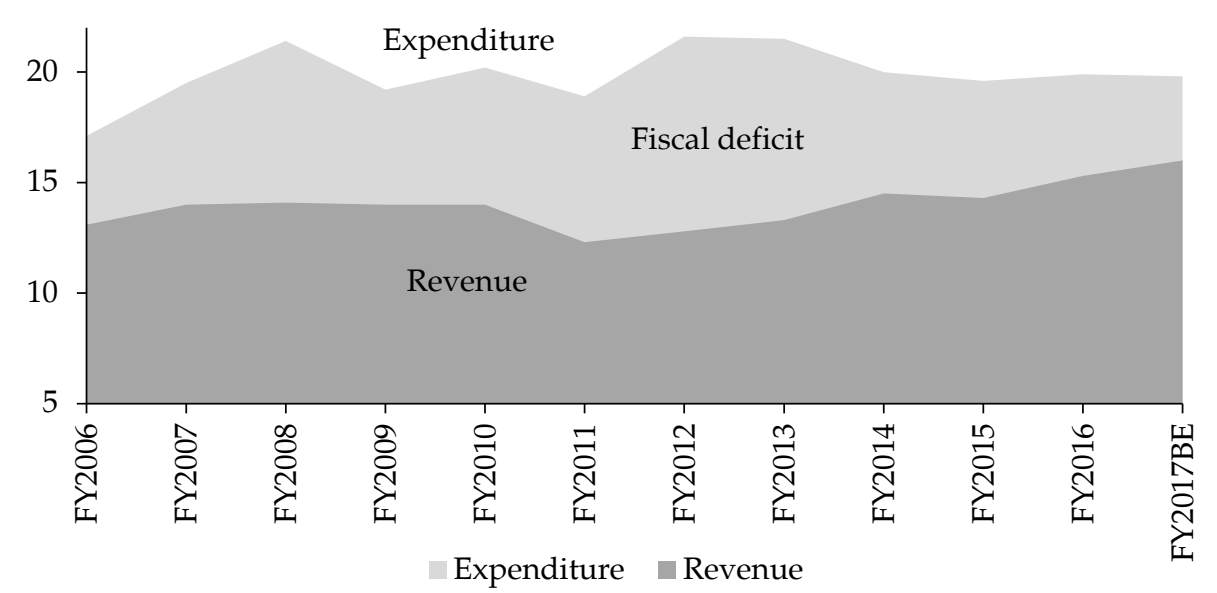

Source: Pakistan Economic Survey for 2016/17.

\section{Literature Review}

There is extensive empirical literature on the impact of the fiscal deficit on economic growth. Using cross-sectional data, Fischer (1993) finds a negative relationship between the budget deficit and economic growth - a finding supported by Easterly and Rebelo (1993). In the case of Pakistan, several studies show a negative association between the fiscal deficit and economic growth (see, for example, Ali \& Ahmad, 2010; Fatima, Ahmed \& Rehman, 2011, 2012; Iqbal \& Zahid, 1998; Shabbir \& Mahmood, 1992). Others find that this relationship is insignificant (see Ahmad, 2013; Nayab, 2015). On the other hand, Gupta et al. (2005) find a positive relationship between the budget deficit and economic growth both in the short and long terms. They also find that productive and nonproductive expenditures both have a positive impact. Bose, Haque and Osborn (2007) consider the type of public spending and show that, if the budget deficit is due to productive spending, its impact on economic growth is positive.

These contradictory findings have prompted researchers to investigate the possibility of a nonlinear relationship between the fiscal deficit and economic growth that captures both the negative and positive association between the two. The idea is that there may be a threshold level of fiscal deficit below which it can help promote economic growth and above which it hampers growth. 
Fay and Porter (2006) argue that the threshold effect depends on the relative importance of country-specific factors such as the intergenerational distributive effects of a deficit. These include the change in the debt burden, the composition of taxes and spending, macroeconomic indicators (growth, savings and inflation), national debt levels and the expected impact of certain political and procedural aspects of the budget process. They also argue that imposing restrictions by fixing the fiscal deficit level compels elected representative to act within set constraints.

Adam and Bevan (2005) estimate the threshold level of fiscal deficit for a panel of 45 developing countries, using the bootstrap method. They find evidence of a threshold effect at a fiscal deficit of about 1.5 percent of GDP for developing countries. Other studies, however, point to far higher threshold levels for developing economies. For example, Onwioduokit (2012) identifies 5 percent of GDP as the threshold level of fiscal deficit for Western African Monetary Zone countries. Similarly, Onwioduokit (2013) puts the estimated threshold level for Sierra Leone at 7 percent of GDP, arguing that a budget deficit beyond this point is detrimental to growth.

Onwioduokit and Bassey (2014) estimate the threshold level of deficit for the Gambia at 6 percent of GDP. Using a threshold autoregressive model, Aero and Ogundipe (2016) investigate the effect of a fiscal deficit on growth in Nigeria and establish a threshold level of 5 percent of GDP. Overall, the empirical literature shows that the threshold level of fiscal deficit ranges between 1.5 to 7 percent of GDP, depending on countryspecific characteristics such as the structure and openness of the economy, the political system and institutional arrangements.

Some studies have explored the possibility of a nonlinear relationship between the fiscal deficit and economic growth in Pakistan. Ali and Ahmad (2010) show that the fiscal deficit has a positive effect on growth up to a threshold level beyond which the impact becomes negative. In a recent contribution, Qasim et al. (in press) find a threshold level of fiscal deficit equal to 0.74 percent of GDP for Pakistan. These studies, however, lack formal theoretical frameworks and use simple nonlinear equations that fail to capture the smooth transition of variables. In contrast, the present study relies on a rigorous theoretical framework and uses the STAR model - applied to time-series data - to estimate the threshold level of fiscal deficit. This method finds considerable support in the literature: various studies show that the STAR model is an efficient nonlinear approach to estimating threshold levels (see, for example, van Dijk, Teräsvirta \& Franses, 2002; Nawaz, Iqbal \& Anwar, 2014; Teräsvirta, 1998). 


\section{Theoretical Model, Data and Methodology}

The impact of the fiscal deficit on economic growth varies across theoretical perspectives, including the neoclassical and Keynesian schools and the rational expectations hypothesis. This is discussed below, followed by a description of the data and model used.

\subsection{Theoretical Model}

Under the neoclassical approach, fiscal deficits are thought to reduce economic growth by putting pressure on the interest rate and thus crowding out private investment (Saleh \& Harvie, 2005). The Keynesian school postulates that an increase in government spending leads to higher growth by stimulating aggregate demand (Nawaz \& Khawaja, 2016). The fiscal deficit causes an increase in domestic production, which makes private investors more optimistic about the future of the economy, thereby resulting in greater investment - referred to by Bernheim (1989) as "crowding in". Under this framework, an expansionary fiscal policy raises the overall fiscal deficit and the government absorbs part of the private savings thus generated to finance the deficit. The rise in the fiscal deficit increases aggregate demand, which in turn promotes employment and output. According to the rational expectations school, however, the fiscal deficit has no role in stimulating economic activity: rational agents adjust their spending because they expect taxation to increase to finance this deficit (Barro, 1989; Saleh \& Harvie, 2005).

To conceptualize the role of the fiscal deficit in economic growth, we use the growth model proposed by Mankiw, Romer and Weil (1992), adding the fiscal deficit as an explanatory variable. We assume a Cobb-Douglas production function with constant returns to scale for the entire economy, as given below:

$y_{i t}=A_{t} k_{t}^{\alpha} h_{t}^{\beta} F D_{t}^{\gamma} e^{\varepsilon_{t}}$

where $y$ is per capita real output, $k$ is the stock of physical capital, $h$ is the stock of human capital and $F D$ is the fiscal deficit. $A_{t}$ is the deterministic term, measured as $A_{t}=C_{0} \exp (d t)$, where $C_{0}$ is a constant, $(d t)$ is a linear time trend, and $\alpha, \beta$ and $\gamma$ are parameters with respect to physical capital, human capital and the fiscal deficit. $\varepsilon_{t}$ is a white-noise error term.

After applying log transformation and substituting for the value of $A_{t}$, the function can be written as follows: 
$\log \left(y_{t}\right)=\log C_{0}+d t+\alpha \log \left(k_{t}\right)+\beta \log \left(\mathrm{h}_{t}\right)+\gamma \log \left(F D_{t}\right)+\varepsilon_{t}$

Based on the recent literature, we assume that the fiscal deficit may follow a nonlinear path. To incorporate the possibility of nonlinearity in the model, this study uses a two-regime logistic STAR model. The standard STAR model with a logistic transition function has the following form:

$\log \left(y_{t}\right)=\alpha+b_{1} \log \left(k_{t}\right)+c_{1} \log \left(\mathrm{h}_{t}\right)+d_{1} \log \left(\mathrm{FD}_{t}\right)+\left(b_{2} \log \left(k_{t}\right)+\right.$ $\left.c_{2} \log \left(\mathrm{h}_{t}\right)+d_{2} \log \left(\mathrm{FD}_{t}\right)\right) G\left(q_{t-j}, \gamma, \theta\right)+\varepsilon_{t}$

where $G\left(q_{t-j}, \gamma, \theta\right)$ is the transition function of the observable variable $q_{t-j}$. To capture any nonlinearity between the variables, we employ a logistic transition function:

$G\left(q_{t-j}, \gamma, \theta\right)=\left[1+\exp \left(-\gamma\left(q_{t-j}-\theta\right)\right)\right]^{-1}$

where the parameter $\gamma$ determines the slope of the transition function. The condition $\gamma>0$ determines the smoothness of the transition function and the value of $\gamma$ indicates the speed of transition from one regime to another.

\subsection{Data}

The empirical analysis is based on time-series data for the period 1972-2014. Data on per capita GDP at constant prices, physical capital and human capital is taken from the Penn World Table 9.0 (published by the Groningen Growth and Development Centre). Real GDP per capita is calculated by dividing the real GDP by the population. The capital stock is based on the accumulation and depreciation of past investments and is estimated using the perpetual inventory method (see Feenstra, Inklaar \& Timmer, 2015). Human capital is measured by the human capital index, which is based on years of schooling and the return on education. ${ }^{1}$ The budget deficit data is taken from the Pakistan Economic Survey for 2016/17 and the State Bank of Pakistan's Handbook of Statistics for 2015. The budget deficit is computed as the difference between expenditure and revenue, divided by GDP. Log transformations are applied to all the variables.

${ }^{1}$ For more detail, see http://www.rug.nl/ggdc/docs/human_capital_in_pwt_90.pdf and Feenstra et al. (2015). 


\subsection{Methodology}

The stationary properties of the time-series variables are examined using the augmented Dickey-Fuller (ADF) test (see Dickey \& Fuller, 1979). Following this, the study uses the autoregressive distributed lag (ARDL) bounds testing approach to cointegration proposed by Pesaran, Shin and Smith (2001) to examine the long-run relationship between the variables. ${ }^{2}$

We employ the STAR model developed by Teräsvirta (1998) to estimate the threshold level of fiscal deficit for Pakistan. The model is an extension of the autoregressive model and is used widely to estimate nonlinear relationships in time-series data because it allows smoother transitions across different regimes. To control the regime-switching process, the STAR model uses logistic and exponential functions instead of the indicator function used in threshold autoregressive models (see Nawaz et al., 2014). Van Dijk et al. (2002) show that the STAR model is suited to the regime-switching procedure for assessing the nonlinear dynamics of variables. The modelling cycle comprises the following steps:

- Specify a linear autoregressive model of order $p$ using the appropriate model selection criteria. This provides the basis for a nonlinear model.

- Test the null hypothesis of linearity against the alternative of STAR nonlinearity. If the test fails to reject linearity, select the appropriate transition variable $s_{t}$ from among the possible variables. The form of the transition function $G\left(s_{t}, \gamma, \theta\right)$ can be either logistic or exponential.

- Estimate the parameters using the appropriate STAR model selected in the previous step.

- Gauge the model's adequacy using various diagnostic tests such as serial correlation, uneven variance and normality. Modify if necessary to obtain an appropriate STAR model.

- Use the final model for descriptive and forecasting purposes.

\section{Results and Discussion}

The study's descriptive statistics are given in Table 2, indicating the mean range and scale of the relationship between the variables. The average

\footnotetext{
2 To examine the stability of the ARDL bounds testing approach to cointegration, we use the CUSUM and CUSUMSQ stability tests. The Akaike information criterion is used to select the optimal lag length.
} 
$\log$ of GDP per capita is 7.8 while the average log of the budget deficit is 1.82 and ranges from 0.83 to 2.32 . The correlation coefficient matrix shows that physical capital and human capital have a positive and significant correlation with GDP per capita. The budget deficit has a negative and significant correlation with GDP per capita. These observations suggest that the budget deficit has a negative effect on economic growth.

Table 2: Descriptive statistics

\begin{tabular}{lcccc}
\hline Statistics & $\boldsymbol{L n y}_{\boldsymbol{t}}$ & $\boldsymbol{L n k}_{\boldsymbol{t}}$ & $\mathbf{L n h}_{\boldsymbol{t}}$ & $\boldsymbol{L n F D}_{\boldsymbol{t}}$ \\
\hline Mean & 7.87 & 8.19 & 0.38 & 1.82 \\
Maximum & 8.44 & 9.01 & 0.59 & 2.32 \\
Minimum & 7.49 & 7.68 & 0.19 & 0.83 \\
SD & 0.27 & 0.43 & 0.14 & 0.32 \\
Observations & 43 & 43 & 43 & 43 \\
\hline Correlation & & & & \\
Lny & 1 & & & \\
Lnk $_{t}$ & $0.9255^{*}$ & 1 & & \\
Lnh $_{t}$ & $0.9377^{*}$ & $0.9325^{*}$ & 1 & \\
LnFD $_{t}$ & $-0.3089^{*}$ & $-0.3911^{*}$ & $-0.5346^{*}$ & 1 \\
\hline
\end{tabular}

Note: ${ }^{*}=$ statistically significant at 5 percent.

Source: Authors' calculations.

The stationary characteristics of the series are examined using the ADF test (Table 3). The Akaike information criterion is used to select the lag structure. The results show that all the variables are nonstationary and they become stationary following a difference transformation, which indicates that all the variables are integrated of order 1 .

Table 3: Results of ADF unit root test

\begin{tabular}{lllllll}
\hline \multirow{2}{*}{ Variable } & \multicolumn{3}{c}{ At level } & \multicolumn{3}{c}{ At first difference } \\
\cline { 2 - 7 } & Intercept & $\begin{array}{c}\text { Intercept } \\
\text { and trend }\end{array}$ & Result & Intercept & $\begin{array}{c}\text { Intercept } \\
\text { and trend }\end{array}$ & Result \\
\hline Lny $_{t}$ & 2.20 & -0.17 & NS & -5.00 & -5.61 & $\mathrm{~S}$ \\
Lnk $_{t}$ & 2.53 & -1.18 & NS & -5.23 & -5.45 & $\mathrm{~S}$ \\
$\operatorname{Lnh}_{t}$ & -0.13 & -1.01 & NS & -5.79 & -5.73 & $\mathrm{~S}$ \\
LnFD $_{t}$ & -2.64 & -3.20 & NS & -8.13 & -8.02 & $\mathrm{~S}$ \\
\hline
\end{tabular}

Note: Critical values $=-3.60,-2.94$ and -2.61 at 1,5 and 10 percent, respectively, with intercept, and $-4.20,-3.52$ and -3.19 at 1,5 and 10 percent, respectively, with intercept and trend.

Source: Authors' calculations. 
To examine the long-run relationship between variables and select an appropriate linear model, we use the ARDL bounds testing approach to co-integration. The results confirm the long-run relationship between GDP per capita, physical capital, human capital and the budget deficit (F-statistic $=5.54$ at 95 percent, with a lower bound of 4.29 and an upper bound of 5.61). This linear model serves as a benchmark for the STAR model. The estimation results show that the fiscal deficit has a nonlinear impact on economic growth. Within the logistic smooth transition function, the appropriate transition variable is the fiscal deficit. Using this as the threshold variable, we develop a logistic STAR model with two regime shifts - a monotonic change in the parameter from linear to nonlinear.

The model's estimation results are given in Table 4, along with the results of the diagnostic tests used to ensure its specificity. The normality test statistic is consistent with the model's requirements and the variance is not uneven. As Figure 2 shows, the model is very closely fitted: GDP per capita follows the model with significant precision.

Figure 2: Real and fitted GDP per capita

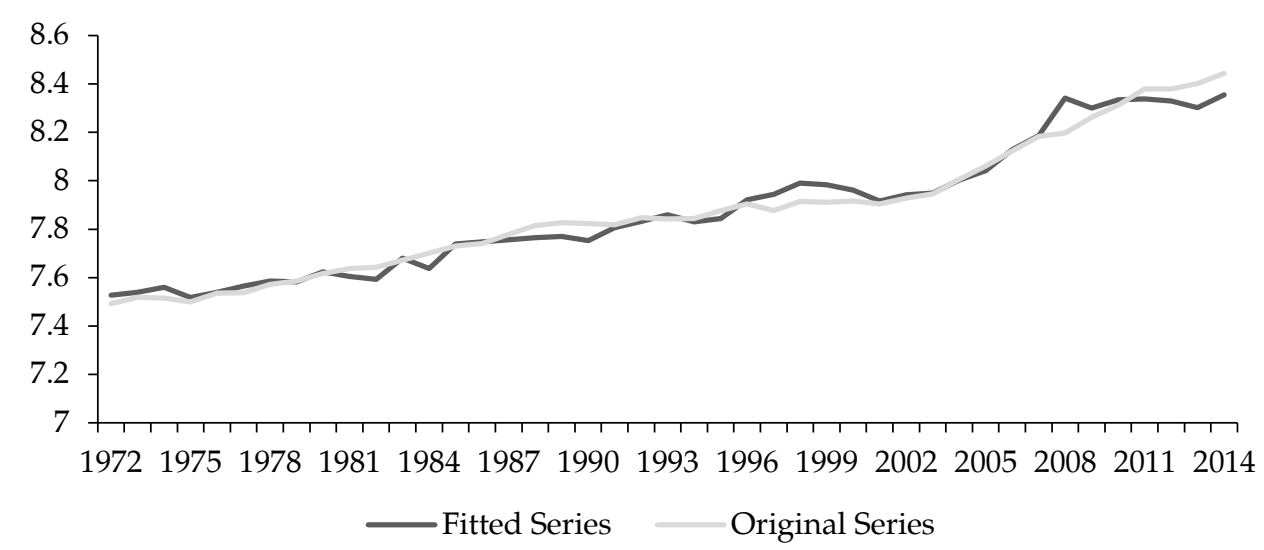

The slope coefficient is equal to 2.46, indicating a slow transition from regime 1 to regime 2. The threshold value of the fiscal deficit is 5.57 (based on a logarithmic value of 1.46). Figure 3 traces the behavior of the transition variable (fiscal deficit) around the threshold value. The fiscal deficit generally remains above the threshold level, indicating that the fiscal deficit has been a potential constraint to growth in Pakistan over time. 
Figure 3: Behavior of transition variable around threshold value

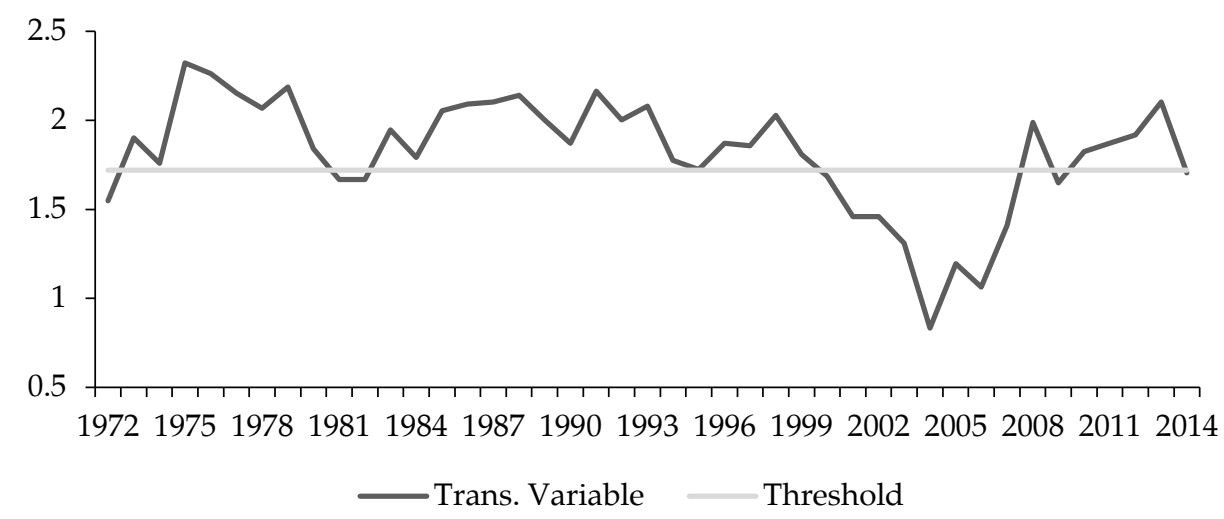

Table 4 shows that there is a negative but insignificant association between the fiscal deficit and economic growth under the first regime. After reaching the threshold level, the impact of the fiscal deficit on growth becomes significant. The estimated coefficient is -0.06 , which is significant at the 1 percent level. This implies that, if the budget deficit is above the threshold level (5.57 percent of GDP), a 1 percent increase in the budget deficit will reduce GDP per capita by 0.06 percent. On the other hand, if the budget deficit is below the threshold level, it has an insignificant impact on GDP per capita. These findings are consistent with the threshold levels estimated for other developing countries, for example, 5 percent of GDP for Nigeria (Aero \& Ogundipe, 2016) and 6 percent of GDP for the Gambia (Onwioduokit \& Bassey, 2014). 
Table 4: STAR model with logistic transition function estimates

\begin{tabular}{lccc}
\hline Variables & Coefficient & SE & t-stat \\
\hline Linear part of model & & & \\
$L n k_{t}$ & 0.78 & 0.27 & $2.95^{* * *}$ \\
$L n h_{t}$ & -0.20 & 0.71 & -0.28 \\
$L n F D_{t}$ & -0.07 & 0.22 & -0.34 \\
Constant & 1.54 & 1.03 & 1.49 \\
\hline Nonlinear part of model & & & \\
Lnk & & 0.34 & $-2.74^{* * *}$ \\
$L n h_{t}$ & -0.94 & 0.96 & $2.84^{* * *}$ \\
LnFD $_{t}$ & 2.72 & 0.02 & $-2.60^{* * *}$ \\
Constant & -0.06 & 2.51 & $2.80^{* * *}$ \\
Slope parameter $\gamma$ & 7.03 & 1.24 \\
Threshold extreme $C$ & 2.46 & 1.98 & $17.42^{* * *}$ \\
$\bar{R}^{2}$ & 1.72 & 0.10 & \\
ARCH-LM test [p-value (F)] & & & \\
[t-stat] & 0.97 & & \\
Normality test (JB test) [p-value (chi sq.)] & 0.51 & & \\
[t-stat] & {$[6.09]$} & & \\
\hline
\end{tabular}

Source: Authors' calculations.

To investigate further the nonlinear behavior of the fiscal deficit visà-vis economic growth, we divide the study period 1993-2016 into four regimes: (i) regime 1 (1993-2001), a low-growth or recession period; (ii) regime 2 (2002-07), a high-growth or boom period; (iii) regime 3 (2008-13), a low-growth or recession period; and (iv) regime 4 (2014-16), a recovery period. Figure 4 demonstrates the relationship between the fiscal deficit and GDP growth under these four different regimes. The dotted line indicates the threshold level of fiscal deficit (5.57). During high-growth periods, the budget deficit lies below the threshold level; during low-growth periods, it is higher than the threshold level. Moreover, during the recovery period, the fiscal deficit shows a declining trend. 


\section{Figure 4: Comparative analysis of two regimes}

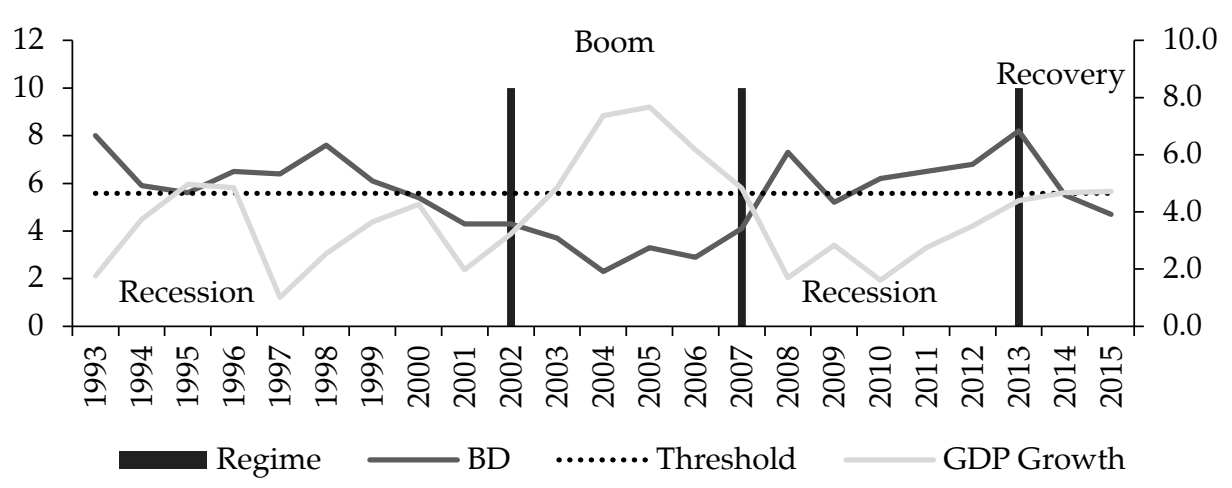

The analysis above shows that the fiscal deficit in Pakistan has generally exceeded the threshold level over time, with adverse consequences for economic growth. Clearly, keeping the fiscal deficit below the threshold level could potentially yield better growth outcomes. However, the benefits of such a policy will only materialize if prudent macroeconomic policies are adopted to channel resources into productive public investment, thereby boosting productivity and enhancing competitiveness among private investors. A fiscal policy that is geared toward raising the long-term growth potential of the economy could set in motion a virtuous cycle in which public investments complement private investments, thus enhancing productive capacity. In turn, a stronger economy would help fiscal consolidation, promote macroeconomic stability, improve investor confidence and sustain growth momentum.

\section{Conclusion and Policy Recommendations}

This study revisits the relationship between the fiscal deficit and economic growth in Pakistan to determine whether there exists a threshold level of fiscal deficit that could serve as a policy benchmark in promoting growth through fiscal expansion. The analysis applies the STAR model to time-series data for the period 1972-2014. We find that the threshold level of fiscal deficit in Pakistan is 5.57 percent of GDP. Historically, the fiscal deficit has had a negative impact on economic growth in Pakistan, having generally remained above the threshold level. This shows that macroeconomic policy needs to keep the fiscal deficit below the threshold level to avoid its adverse consequences for growth. 
It may be tempting to argue that running a fiscal deficit below the threshold level is desirable because fiscal expansion within acceptable limits would spur economic activity and encourage growth. However, the benefits of such a policy will be realized only if public spending targets long-term investments that yield adequate returns on infrastructure, education, health and other development projects. Such public investments might also improve the marginal productivity of private capital. This implies that, if public capital were to complement private capital, then investing in public capital would "crowd in" private investment, thereby reinforcing the process of economic growth.

Finally, it needs to be cautioned that the threshold level of fiscal deficit does not represent an optimal level of deficit ensuring inter-temporal solvency conditions. It merely indicates a level of fiscal deficit that policymakers could use as a benchmark, beyond which fiscal expansion could potentially hamper economic growth. Furthermore, the threshold level may be conditional on the composition of deficit financing i.e. the threshold level of the fiscal deficit could rise or fall as a result of changes in methods of deficit financing. Future research could investigate how the threshold level of fiscal deficit depends on different financing options, including public borrowing and seigniorage. 


\section{References}

Adam, C. S., \& Bevan, D. L. (2005). Fiscal deficits and growth in developing countries. Journal of Public Economics, 89(4), 571-597.

Aero, O., \& Ogundipe, A. A. (2016). Fiscal deficit and economic growth in Nigeria: Ascertaining a feasible threshold. Unpublished manuscript, Covenant University, Ota, Nigeria. Retrieved from https://ssrn.com/abstract=2861505

Ahmad, N. (2013). The role of budget deficit in the economic growth of Pakistan. Global Journal of Management and Business Research, 13(5), 1-5.

Ali, S., \& Ahmad, N. (2010). The effects of fiscal policy on economic growth: Empirical evidences based on time series data from Pakistan. Pakistan Development Review, 49(4), 497-512.

Barro, R. J. (1989). The Ricardian approach to budget deficits. Journal of Economic Perspectives, 3(2), 37-54.

Bernheim, B. D. (1989). A neoclassical perspective on budget deficits. Journal of Economic Perspectives, 3(2), 55-72.

Bose, N., Haque, M. E., \& Osborn, D. R. (2007). Public expenditure and economic growth: A disaggregated analysis for developing countries. The Manchester School, 75(5), 533-556.

Dickey, D. A., \& Fuller, W. A. (1979). Distribution of the estimators for autoregressive time series with a unit root. Journal of the American Statistical Association, 74(366), 427-431.

Easterly, W., \& Rebelo, S. (1993). Fiscal policy and economic growth: An empirical investigation. Journal of Monetary Economics, 32(3), 417-458.

Fatima, G., Ahmed, A. M., \& Rehman, W. (2011). Fiscal deficit and economic growth: An analysis of Pakistan's economy. International Journal of Trade, Economics and Finance, 2(6), 501-504.

Fatima, G., Ahmed, M., \& Rehman, W. (2012). Consequential effects of budget deficit on economic growth of Pakistan. International Journal of Business and Social Science, 3(7), 203-208. 
Fay, W., \& Porter, R. (2006). Optimal budget deficits (Briefing Paper No. 28). Paper prepared for the Federal Budget Policy Seminar, Harvard Law School, Cambridge, MA.

Feenstra, R. C., Inklaar, R., \& Timmer, M. P. (2015). The next generation of the Penn World Table. American Economic Review, 105(10), 3150-3182.

Fischer, S. (1993). The role of macroeconomic factors in growth. Journal of Monetary Economics, 32(3), 485-512.

Gupta, S., Clements, B., Baldacci, E., \& Mulas-Granados, C. (2005). Fiscal policy, expenditure composition and growth in low-income countries. Journal of International Money and Finance, 24(3), 441-463.

Iqbal, N., Khan, S. J. I., \& Irfan, M. (2008). Democracy, autocracy and macroeconomic performance in Pakistan. Kashmir Economic Review, 17(1), 61-88.

Iqbal, Z., \& Zahid, G. M. (1998). Macroeconomic determinants of economic growth in Pakistan. Pakistan Development Review, 37(2), 125-148.

Khan, M. S., \& Senhadji, A. S. (2001). Threshold effects in the relationship between inflation and growth. IMF Staff Papers, 48(1), 1-21.

Mankiw, N. G., Romer, D., \& Weil, D. N. (1992). A contribution to the empirics of economic growth. Quarterly Journal of Economics, 107(2), 407-437.

Nawaz, S., Iqbal, N., \& Anwar, S. (2014). Modelling electricity demand using the STAR (smooth transition autoregressive) model in Pakistan. Energy, 78, 535-542.

Nawaz, S., \& Khawaja, M. I. (2016). Fiscal policy, institutions and growth: New insights. Singapore Economic Review. https://doi.org/10.1142/S0217590816500296

Nayab, H. (2015). The relationship between budget deficit and economic growth of Pakistan. Journal of Economics and Sustainable Development, 6(11), 85-90.

Onwioduokit, E. A. (2012). An empirical estimation of the optimal level of fiscal deficit in the West African Monetary Zone. Journal of Monetary and Economic Integration, 12(1), 1-33. 
Onwioduokit, E. A. (2013). Threshold analysis of budget deficit and economic growth in Sierra Leone. West African Financial and Economic Review, 10(1), 93-121.

Onwioduokit, E. A., \& Bassey, G. E. (2014). Fiscal deficit and economic growth in the Gambia: A search for threshold. Developing Country Studies, 4(19), 162-181.

Pakistan, Ministry of Finance. (2017). Pakistan economic survey 2016-17. Available from http://www.finance.gov.pk/survey_1617.html

Pesaran, M. H., Shin, Y., \& Smith, R. J. (2001). Bounds testing approaches to the analysis of level relationships. Journal of Applied Econometrics, 16(3), 289-326.

Qasim, A. W., Kemal, M. A., \& Siddique, O. (in press). Fiscal consolidation and economic growth: Insights from the case of Pakistan. Pakistan Development Review.

Saleh, A. S., \& Harvie, C. (2005). The budget deficit and economic performance: A survey. Singapore Economic Review, 50(2), 211-243.

Shabbir, T., \& Mahmood, A. (1992). The effects of foreign private investment on economic growth in Pakistan. Pakistan Development Review, 31(4), 831-841.

State Bank of Pakistan. (2015). Handbook of statistics on Pakistan economy 2015. Retrieved from http://www.sbp.org.pk/departments/stats/PakEconomy_Hand Book/index.htm

State Bank of Pakistan. (2016). Annual report 2015-2016 (state of the economy). Retrieved from http://www.sbp.org.pk/reports/annual/arFY16/Anul-indexeng-16.htm

Teräsvirta, T. (1998). Modelling economic relationships with smooth transition regressions. In A. Ullah \& D. E. A. Giles (eds.), Handbook of applied economic statistics (chap. 15). Boca Raton, FL: CRC Press.

van Dijk, D., Teräsvirta, T., \& Franses, P. H. (2002). Smooth transition autoregressive models: A survey of recent developments. Econometric Reviews, 21(1), 1-47. 


\section{Appendix}

Figure A1: Transition function

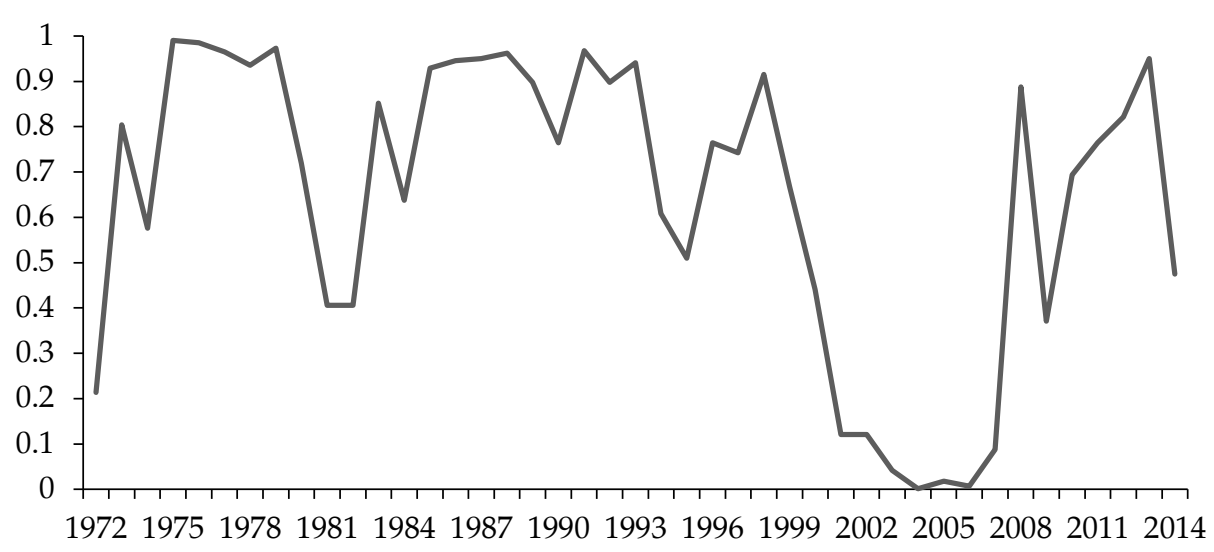

Figure A2: Cross plot for $G\left(L n \_B D(t)\right)$

Crossplot $\mathrm{G}\left(\ln \_\mathrm{bd}(\mathrm{t})\right)$

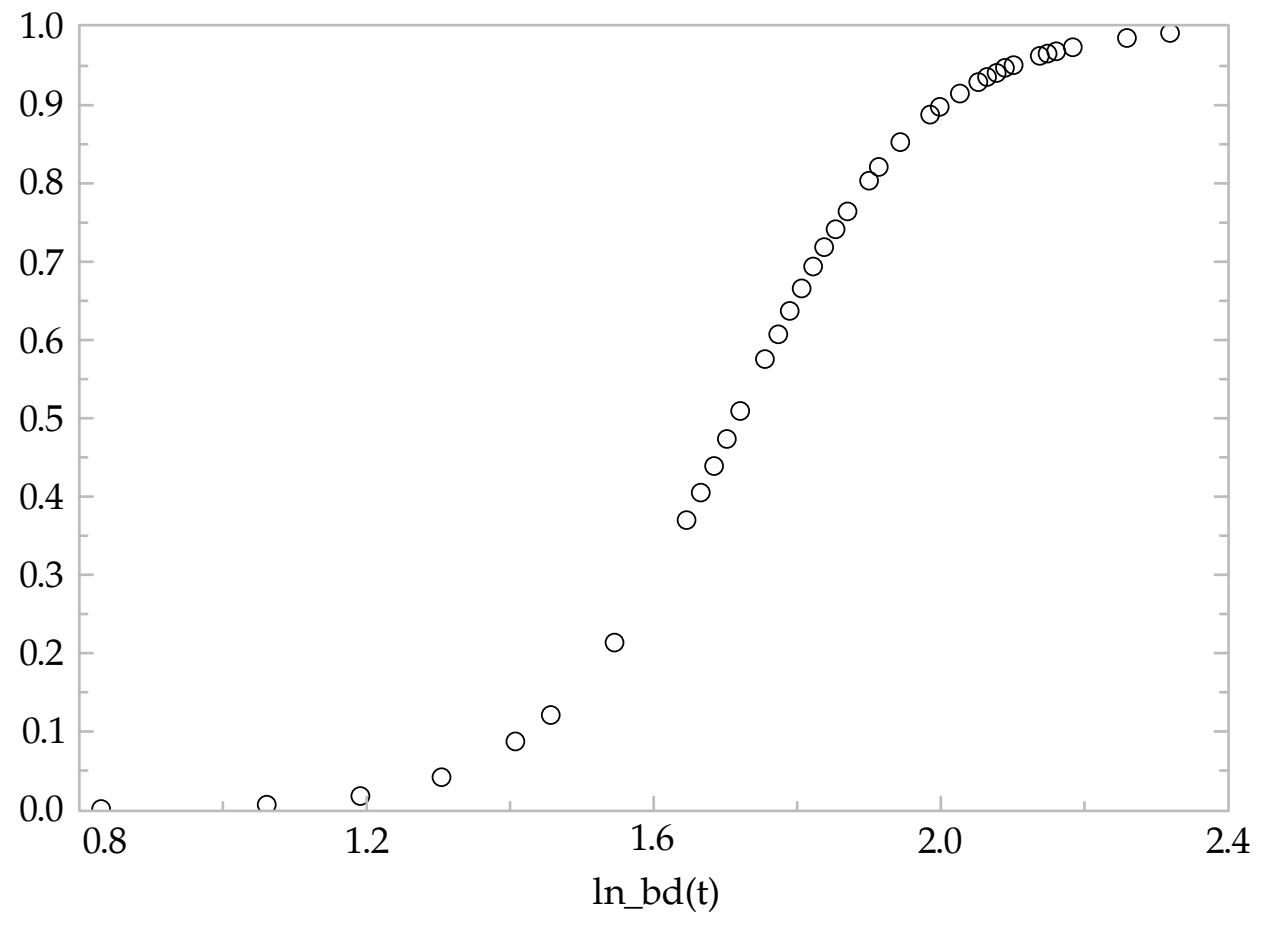


Figure A3: Linear and nonlinear components of the model

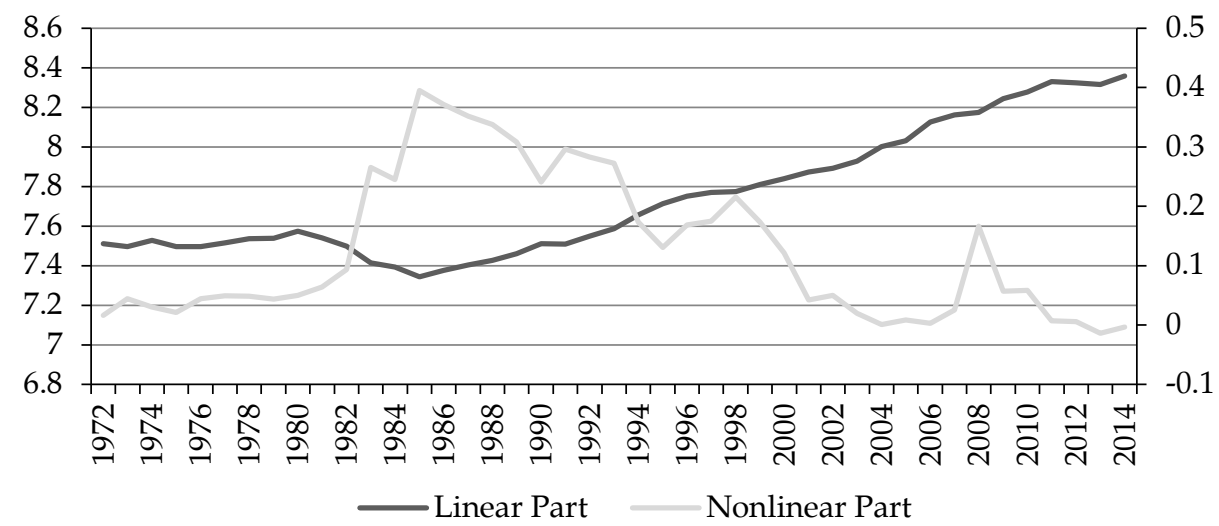

